\title{
Sperm channel diversity and functional multiplicity
}

\author{
Alberto Darszon, Juan J Acevedo ${ }^{1}$, Blanca E Galindo, Enrique O Hernández-González² \\ Takuya Nishigaki, Claudia L Treviño, Chris Wood and Carmen Beltrán
}

Department of Genetics of Development and Molecular Physiology, Institute of Biotechnology, UNAM, Cuernavaca, Mexico, 'Department of Physiology and Pathophysiology, School of Medicine, UAEM, Cuernavaca, Mexico and ${ }^{2}$ Department of Cell Biology, Center for Research and Advanced Studies, Instituto Politécnico Nacional, Mexico City, Mexico

Correspondence should be addressed to A Darszon, Departamento de Genética del Desarrollo y Fisiología Molecular, Instituto de Biotecnología, Universidad Nacional Autónoma de México, Adpo. Postal 510-3, Cuernavaca, Morelos 62250, Mexico; Email: darszon@ibt.unam.mx

\begin{abstract}
Ion channels are extraordinarily efficient machines that move ions in diversely controlled manners, allowing cells to rapidly exchange information with the outside world and with other cells. Communication is the currency of fertilization, as it is of most fundamental cell signaling events. Ion channels are deeply involved in the dialogue between sperm, its surroundings, and the egg. How sperm swim, find the egg and fertilize it depend on ion permeability changes modulated by environmental cues and components of the egg outer layer. Different ion channels distinctly localized in these tiny, amazing cells perform specific decoding functions that shape the sophisticated behavior of sperm. It is not surprising that certain sperm ion channels are turning out to be unique. New strategies to characterize sperm ion transport have opened exciting possibilities to dissect sperm-egg signaling and unveil novel contraception targets.

Reproduction (2006) 131 977-988
\end{abstract}

\section{Introduction}

Ion channels are amazing membrane proteins that efficiently catalyze ion transport through the non-conducting lipid bilayer. A single ion channel, one single protein, allows millions of ions per second to flow across the membrane. Only a few of these channels are necessary to trigger, in milliseconds, substantial electric and concentration changes in a small cell like sperm. It is not surprising that such remarkable transducers were evolutionarily selected to perform fast information exchanges between the external world and cells or within them. Ionic gradients across cells not only determine membrane potential $\left(E_{m}\right)$ through ionselective channels, permeant ions can modulate enzymes and further influence channel activity causing additional $E_{m}$ changes and ion flow. $E_{m}$ governs the rates and direction of ion-flow through channels and exchangers - its fluctuations modulate intracellular $\mathrm{pH}\left(\mathrm{pH}_{\mathrm{i}}\right)$, intracellular $\mathrm{Ca}^{2+}\left(\left[\mathrm{Ca}^{2+}\right]_{\mathrm{i}}\right)$ and other second messengers that influence sperm maturation, motility and the acrosome reaction (AR).

Mature, competent male and female gametes produced in the testis or ovaries are needed to achieve fusion and fertilization. Identifying the key mechanisms and molecules involved in the sperm-egg dialog remains incomplete. Sea urchins spawn tens of billions of sperm into the sea. Upon release, motility ensues, powered by a microscopic flagellar engine that is exquisitely regulated by chemical signals from the environment and the egg. On the other hand, the potential for motility in sperm from internal fertilizers (reptiles, birds and mammals) develops during their journey through the vas deferens (a duct from the epididymis to the urethra) and the epididymis (Morisawa 1994, Yanagimachi 1994). Activation proceeds when sperm are ejaculated into the female reproductive tract.

Environmental cues activate motility through transduction events involving sperm ion channels (Darszon et al. 2005, Quill et al. 2006). Mammalian sperm have to further mature within the female reproductive tract through a process named capacitation (Visconti et al. 2002). Though millions of sperm are released, only a few reach their goal (Suarez \& Ho 2003). The mechanisms of sperm chemotaxis and its importance for some species still possess intriguing questions (Eisenbach 1999).

Motile mature sperm from all species possessing an acrosome - a large, Golgi-derived secretory vesicle located in the anterior region of the sperm - must undergo the AR to fertilize the homologous egg (Yanagimachi 1994, Neill \& 
Vacquier 2004), during which the acrosomal and plasma membranes fuse at multiple sites. This reaction releases certain components needed for the sperm to penetrate the egg coat and subsequently fuse with the egg plasma membrane. External ions, particularly $\mathrm{Ca}^{2+}$, are remarkably influential on sperm maturation, motility and the AR (Yanagimachi 1994, Jungnickel et al. 2003). These features of sperm function emphasize the essential role ion channels play in the physiology of this important cell.

In this brief review we have attempted to highlight sperm functional aspects where ion channels play a key role (motility, capacitation and AR), and used working models to illustrate testable hypotheses that can contribute to a better understanding of how sperm fertilize eggs. We regret having to be so concise and have had to leave out some important contributions. Excellent recent reviews may make up for these limitations (Baldi et al. 2002, Visconti et al. 2002, Jungnickel et al. 2003, Neill \& Vacquier 2004, Zhang \& Gopalakrishnan 2005, Jimenez-Gonzalez et al. 2006).

\section{Motility}

Motility is perhaps the most easily observed function of sperm, and is yet arguably the least well understood. Ion channels have long been suspected to critically influence sperm motility. However, until recently, direct evidence of involvement in this process has been lacking due to the difficulties in performing experiments with individual motile sperm.

An early hint that ion channels regulate motility came from observations that the composition of the external milieu may have profound effects on this process. Often sperm are maintained immotile in the testes prior to release, in for example, sea urchins, this immotile state is principally maintained by a high extracellular $\mathrm{K}^{+}\left(\left[\mathrm{K}^{+}\right]_{\mathrm{e}}\right)$ (Darszon et al. 2005). Activation of sperm motility occurs upon spawning, owing to the reduction of $\left[\mathrm{K}^{+}\right]_{\mathrm{e}}$. Manipulating the $\left[\mathrm{Ca}^{2+}\right]$ to which permeabilized or demembranated invertebrate or mammalian sperm are exposed alters flagellar bending asymmetry, and high $\left[\mathrm{Ca}^{2+}\right]$ inhibits flagellar motility (Brokaw 1979, Tash \& Means 1982). $\mathrm{Ca}^{2+}$ also plays a critical role in chemotaxis, whereby a sperm responds to a gradient of chemoattractant surrounding the egg, and reorientates its trajectory to swim up the gradient (see Fig. 1). This process has been observed most frequently in the sperm of invertebrate marine animals, but exists also in mammalian and plant (bracken) sperm. In all studied cases, chemotaxis is dependent on the presence of external $\mathrm{Ca}^{2+}$, suggesting that $\mathrm{Ca}^{2+}$-permeant pathways participate in this process.

Mammalian sperm manifest two general forms of motility, activated and hyperactivated. Activated motility, as observed in freshly ejaculated sperm, displays a relatively low-amplitude flagellar beat that propels the sperm through the initial stages of its journey through the female reproductive tract. It is stimulated by Ser/Thr and Tyr phosphorylation of flagellar proteins (reviewed in Turner 2006). The phosphorylation cascade is regulated in part by the action of CAMP on protein kinase A (PKA), which in turn may be activated by stimulation of soluble adenylyl cyclase (sAC). This enzyme is regulated by bicarbonate ions $\left(\mathrm{HCO}_{3}^{-}\right.$) and $\mathrm{Ca}^{2+}$ (Litvin et al. 2003, Esposito et al. 2004). Although the source of the $\mathrm{Ca}^{2+}$ that might upregulate SAC activity is unknown, $\mathrm{Ca}^{2+}$ channels in the plasma membrane are a strong possibility.

Hyperactivated motility is observed in sperm isolated from the upper regions of the female reproductive tract. Initiation of hyperactivated motility often coincides with the onset of capacitation, although the two processes are independent (Ho \& Suarez 2003). It consists of exaggerated, large amplitude flagellar beats that cause the sperm to swim in characteristic 'figure-of-eight' formation in low-viscosity medium. In high-viscosity medium, hyperactivated motility is more progressive (Suarez \& Ho 2003). Hyperactivation is thus thought important for sperm progression through the higher-viscosity environment of the oviduct and possibly for penetration of the egg cumulus.

$\mathrm{Ca}^{2+}$ is required for the initiation and maintenance of hyperactivated motility by directly regulating components of the axonemal machinery. In hyperactivated hamster sperm, transitory increases in $\left[\mathrm{Ca}^{2+}\right]_{i}$ were recorded that temporally correlated with the flagellar beat frequency (Suarez et al. 1993). The source for the $\mathrm{Ca}^{2+}$ appears to be the redundant nuclear envelope (RNE), a reticular structure at the flagellum neck. In bull sperm, agonists of the inositol 1,4,5-trisphosphate $\left(\mathrm{IP}_{3}\right)$ receptor induced hyperactivation, and $I P_{3}$ receptors $\left(I P_{3} R\right)$ were located on the RNE (Ho \& Suarez 2003). In immobilized human sperm, a gradient of progesterone stimulated long-lasting oscillations in $\left[\mathrm{Ca}^{2+}\right]_{i}$ that originated from a sperm head region containing the RNE (Harper et al. 2004). The oscillations correlated with increases in flagellar activity that are comparable to those occurring during hyperactivation. The $\mathrm{Ca}^{2+}$ oscillations were dependent on ryanodine receptor (RyR) activity rather than that of $I P_{3} R s$, in contrast to bull sperm in which RyRs were not detected (Suarez \& Ho 2003, Jimenez-Gonzalez et al. 2006). In both bull sperm and human sperm, the increases and oscillations in $\left[\mathrm{Ca}^{2+}\right]_{i}$ and the motility changes were dependent on external $\mathrm{Ca}^{2+}$, but not immediately, suggesting that this effect is due to an eventual failure to replenish intracellular stores with external $\mathrm{Ca}^{2+}$.

A number of voltage-gated $\mathrm{Ca}^{2+}\left(\mathrm{Ca}_{\mathrm{v}}\right)$ channel subunits have been detected in mammalian sperm (Fig. 2), and $\mathrm{Ca}_{v}$ channel activity has also been measured in spermatogenic cells and sperm (Arnoult et al. 1996, 1999, Wennemuth et al. 2000). $\mathrm{Ca}_{v} 1.2,2.1$ and 2.3 subunits were localized to the proximal piece of mouse sperm flagella (Westenbroek \& Babcock 1999), as was the auxiliary $\beta 3$ subunit (Serrano et al. 1999). Sperm from Ca 2.3 knockout mice displayed increased linearity in their swimming behavior, although mice were normally fertile (Sakata et al. 2002). Additionally, all three T-type $\mathrm{Ca}_{v} 3$ channel subunits have 


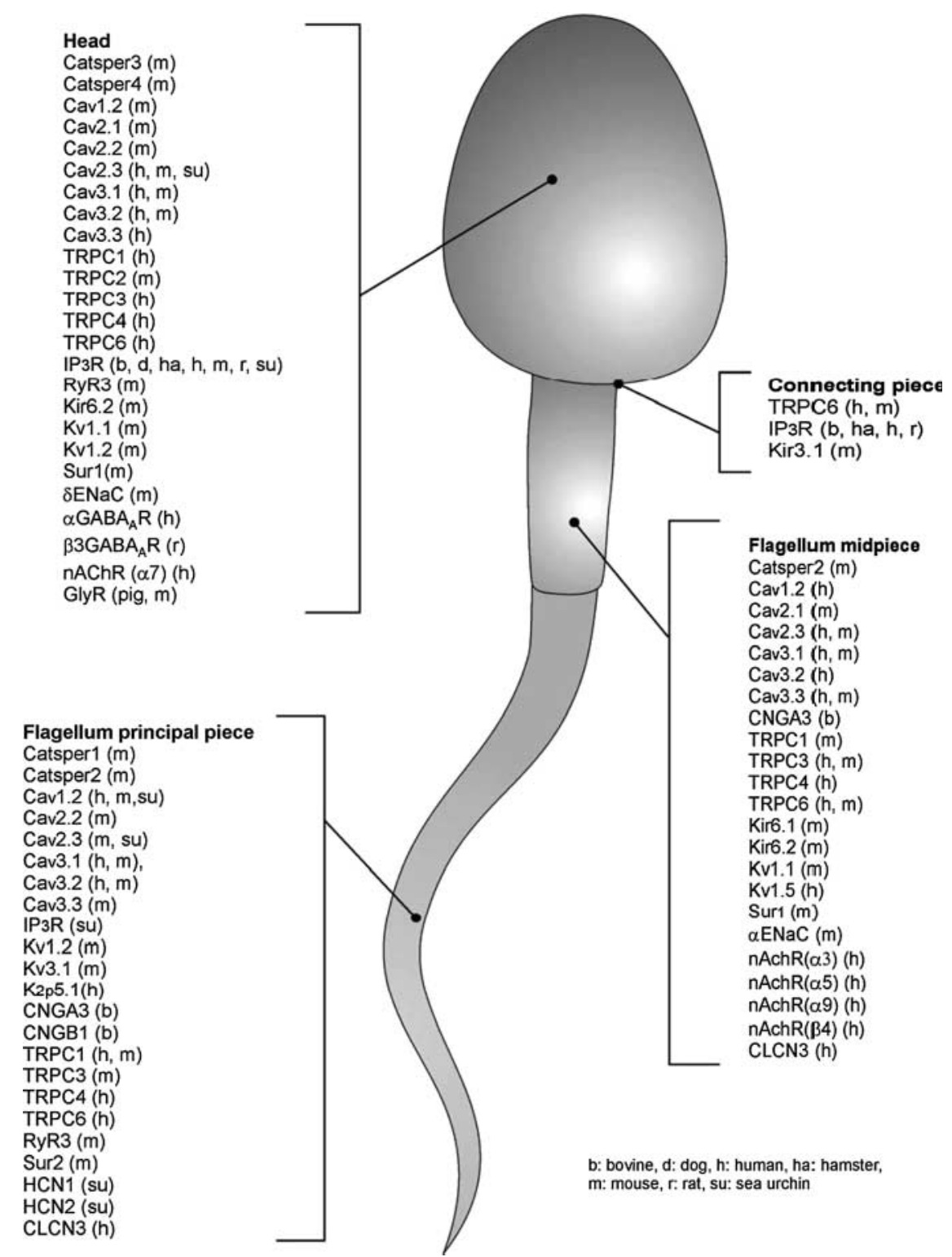

Figure 1 Summary of the different ion channels and their spatial distribution in sperm. The figure includes channels that have been immunolocalized to the region indicated. Additional evidence for the presence of many of these channels such as RT-PCR, in situ hybridization and western blots is available (Darszon et al. 2005). Sea urchin flagella do not have principal and mid pieces, channels found in the flagella of this species are indicated as present in the principal piece. Channels that participate in functions such as volume regulation (not described in the text) have also been included (Yeung et al. 2006).

also been localized to the flagellum of mouse and human sperm (Trevino et al. 2004). Other channels possibly involved in motility belong to the cyclic nucleotide-gated channel family (CNG). The first sperm ion channel cloned and heterologously expressed was from this family (Weyand et al. 1994). These channels were immunolocalized along the length of the flagellum (CNGA3) or confined to the principal piece alone (CNGB1) of bovine sperm (Wiesner et al. 1998) however CNGA3 knockout mice are normally fertile (Turner 2006). Furthermore, members of the transient receptor potential (TRP) channel family have been localized to the flagella of both human (transient receptor potential canonical; TRPC1, C3 and C6) and mouse sperm (TRPC1, C3, C4 and C6), inhibitors of TRP channels blocked human sperm motility (Castellano et al. 2003). The most convincing evidence for the role of ion channels in sperm motility comes from a novel class of $\mathrm{Ca}^{2+}$ channels, named CatSpers, whose expression is confined to the testes. Four members of this family have been described so far, and two of them, CatSpers 1 \& 2, localize to the flagella (Quill et al. 2001, Ren et al. 2001, Lobley et al. 2003, Jin et al. 2005). Knockout mice for catsper 1 are infertile, due to a specific inability to undergo hyperactivation (Ren et al. 2001, Carlson et al. 


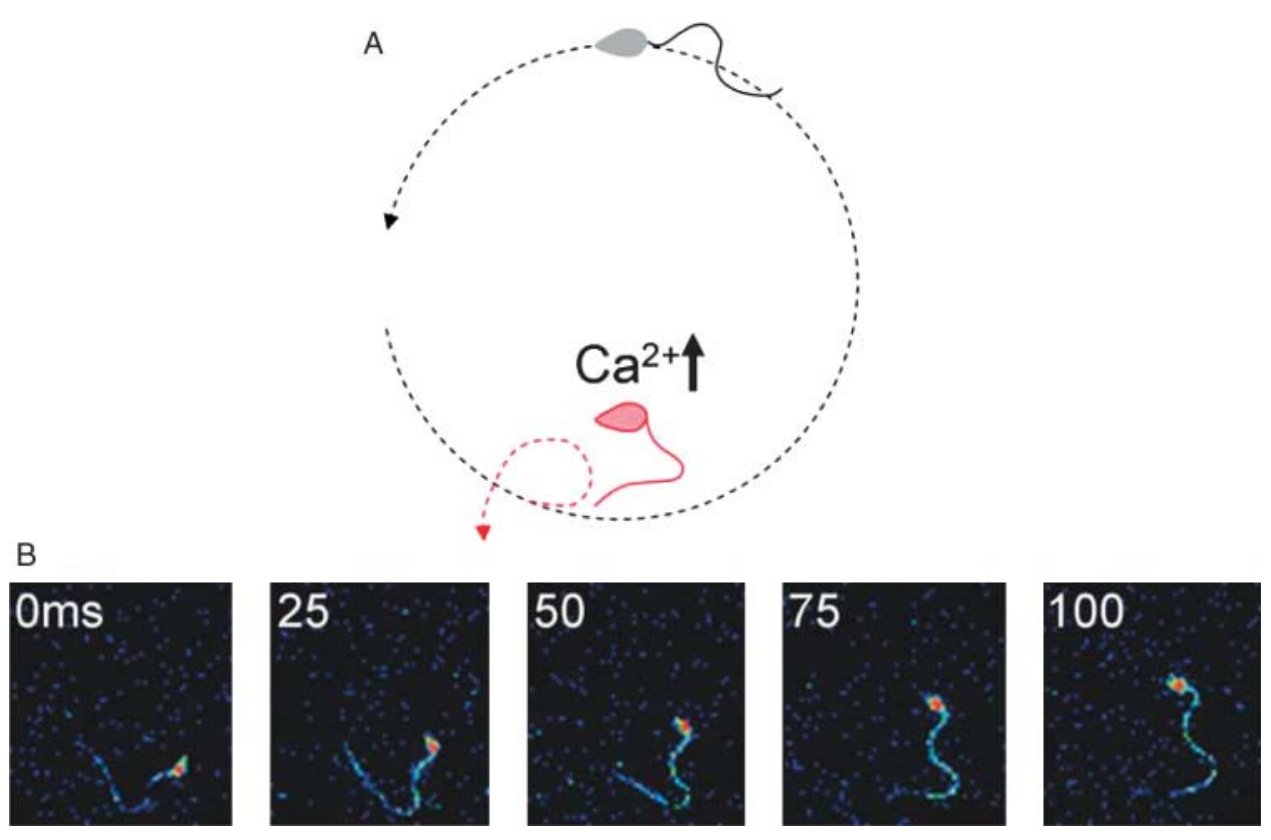

Figure 2 (A) The normal circular trajectory of a sea urchin sperm is interrupted by a sharp turn, caused by a $\mathrm{Ca}^{2+}$-dependent increase in flagellar asymmetry. B) Uncaging of cGMP induces an increase in intracellular $\mathrm{Ca}^{2+}$ and a transient increase in flagellar asymmetry $(0-50 \mathrm{~ms})$ that rapidly recedes $(75-100 \mathrm{~ms}$ ). For experimental details, please see (Wood et al. 2005). Sea urchin sperm swim in a circular pattern because their flagella beat with an inherently asymmetrical sinusoidal waveform (see A). As the plane of the flagellar waveform is slightly skewed, the sperm swim in a helical path in 'open water' that converts to a two-dimensional circular pattern once the sperm encounter a surface, such as the base of a microscopic imaging chamber. This fortuitous detail permits extended observation of motility, as the sperm swim in circles within the microscope field-of-view for prolonged periods. In many species of urchin, egg-derived peptides stimulate the sperm to alter its trajectory by undergoing a transient sharp turn - red trajectory in (A). These turns are necessary, but not sufficient, for chemotaxis, as they are generated in response to egg peptides derived from chemotactic (Arbacia punctulata; Bohmer et al. 2005) and non-chemotactic (S. purpuratus; C Wood unpublished data) species alike. The turn itself results from a transient increase in flagellar asymmetry, which depends on the presence of $\mathrm{Ca}^{2+}$ in the extracellular medium. Recently it was shown that these turns occur in response to a transient increase in intracellular $\mathrm{Ca}^{2+}$ in the flagellum (Bohmer et al. 2005, Wood et al. 2005), although as yet it is not known how such increases are generated. Upon binding to sperm, egg peptides activate a guanylate cyclase, and cGMP levels rise rapidly. Indeed, in the absence of egg peptides, uncaging cGMP inside a swimming sperm is sufficient to stimulate sperm to undergo sharp turns which depend on a rapid increase in intracellular $\mathrm{Ca}^{2+}$ (see (B) and Bohmer et al. 2005, Wood et al. 2005). The link between the increase in cGMP and flagellar $\mathrm{Ca}^{2+}$ is unknown, but one suggestion is that cGMP acts indirectly to increase intracellular $\mathrm{Ca}^{2+}$ by altering another intracellular parameter such as $\mathrm{pH}$ or membrane potential (Darszon et al. 2005, Hildebrand \& Kaupp 2005). Reports of the $\mathrm{pH}$ changes occurring after egg peptide binding or release of cGMP are contradictory, with results from $S$. purpuratus showing that a $\mathrm{pH}$ increase precedes the increase in $\mathrm{Ca}^{2+}$, while data from $A$. punctulata indicate that the $\mathrm{pH}$ increase occurs later (see Darszon et al. 2005, Hildebrand \& Kaupp 2005). Measurements of membrane potential changes in S. purpuratus show a rapid hyperpolarization event occurring before a larger depolarization, which has been proposed to activate a hyperpolarization-sensitive $\mathrm{Na}^{+} / \mathrm{H}^{+}$ exchanger to lead to the increase in $\mathrm{pH}$, and remove inactivation from voltage-sensitive $\mathrm{Ca}^{2+}$ channels which open upon depolarization (see Darszon et al. 2005, Hildebrand \& Kaupp 2005). Antibodies to $\mathrm{Ca}_{v}$ channels label the flagella of sea urchin sperm, and inhibitors of $\mathrm{Ca}_{v}$ channels such as nimodipine and $\mathrm{Ni}^{2+}$ are able to block both the rapid increase in $\mathrm{Ca}^{2+}$ and the turning event upon liberation of cGMP. The main evidence pointing to the importance of the hyperpolarization event is the effect of increasing the $\mathrm{K}^{+}$concentration of the extracellular medium; under such conditions, binding of egg peptides increases the concentration of cGMP, but blocks all downstream changes in $\mathrm{pH}$, membrane potential, $\mathrm{Ca}^{2+}$ and cAMP. Uncaging of cGMP under these conditions produces similar results, unlike uncaging of cAMP which results in increases in intracellular $\mathrm{Ca}^{2+}$ (see Darszon et al. 2005, Hildebrand \& Kaupp 2005). This evidence has been taken to propose a model whereby increases in cGMP activate $\mathrm{K}^{+}$-permeant channels in the membrane by an unknown mechanism, leading to hyperpolarization of the membrane.

2003). These knockout mice also show defects in cAMP and depolarization-induced $\mathrm{Ca}^{2+}$ entry (Ren et al. 2001, Carlson et al. 2003). catsper 1 and catsper 2 knockout mice have identical phenotypes because neither protein alone localizes to the flagellum without co-expression of the other (Quill et al. 2003, Carlson et al. 2005). Whole-cell patch-clamp recordings sealing on cytoplasmic droplets of sperm revealed a constitutively active, weakly voltagedependent $\mathrm{Ca}^{2+}$ current that is strongly potentiated by intracellular alkalinization (Kirichok et al. 2006). This cur- rent is absent in catsper 1 knockout mice, and is localized to the flagella principal piece, demonstrating that CatSper1 is a component of a flagellar $\mathrm{Ca}^{2+}$ channel. Interestingly, simultaneous depolarization and internal alkalinization induced by external $\mathrm{K}^{+}$and $\mathrm{NH}_{4} \mathrm{Cl}$ addition trigger a $\mathrm{Ni}^{2+}$ sensitive $\left[\mathrm{Ca}^{2+}\right]_{i}$ elevation. This voltage dependent channel could contribute to the increase in $\left[\mathrm{Ca}^{2+}\right]_{\mathrm{i}}$ that occurs during capacitation (Fraire-Zamora \& Gonzalez-Martinez 2004) and possibly during hyperactivation. The channel is permeable to $\mathrm{Na}^{+}$in the absence 
of external $\mathrm{Ca}^{2+}$ (Espinosa \& Darszon 1995, GonzalezMartinez 2003).

In invertebrate sperm very little is known of the role of ion channels in regulating motility. The sperm of many marine species demonstrate chemotaxis, and in all known cases this process is dependent on the extracellular $\left[\mathrm{Ca}^{2+}\right]$. In many such situations the chemotactic behavior manifests as a series of turns interspersed with periods of straighter swimming, it is these turns that are inhibited in the absence of external $\mathrm{Ca}^{2+}$. In sea urchin, it was recently shown that cGMP, the first signaling intermediate generated upon binding of egg-derived peptides, may stimulate sperm to undergo chemotaxis-like motility changes that require $\mathrm{Ca}^{2+}$ entry into the flagellum through a specific pathway that is sensitive to inhibitors of $\mathrm{Ca}_{\mathrm{v}}$ channels (see Fig. 2, Wood et al. 2005). Furthermore $\mathrm{Ca}_{\mathrm{v}} 1.2$ and 2.3 have been immunolocalized to the sea urchin sperm flagella (Granados-Gonzalez et al. 2005), hinting at a role for these channels in regulating chemotaxis. The opening of a rapid flagellar $\mathrm{Ca}^{2+}$ entry pathway has also been shown to generate chemotactic turns in a response to a native chemoattractant in a different species of sea urchin (Bohmer et al. 2005). Another $\mathrm{Ca}^{2+}$ channel localized to the flagella of sea urchin sperm is the $\mathbb{I P}_{3}$ receptor (Zapata et al. 1997), a protein usually associated with liberation of $\mathrm{Ca}^{2+}$ from internal $\mathrm{Ca}^{2+}$ stores, of which there are none in the flagella of sea urchin sperm.

Additionally, in sea urchin sperm, two hyperpolarization-activated and cyclic nucleotide-gated channels $(\mathrm{HCN})$ have been immunolocalized to the flagella compartment, namely SpHCN1 (Gauss et al. 1998) and SpHCN2 (Galindo et al. 2005). These channels could open in response to the hyperpolarization event(s) and/or increases in cyclic nucleotides that follow binding of egg peptides, and an inhibitor of HCN channels alters the kinetics of the early $\left[\mathrm{Ca}^{2+}\right]_{i}$ changes induced by such peptides (Nishigaki et al. 2004).

In ascidian sperm, an egg-derived factor both activates sperm motility and stimulates chemotaxis. Sperm activation is sensitive to inhibitors of $\mathrm{Ca}_{v}$ channels, and chemotaxis is blocked by an inhibitor of store-operated $\mathrm{Ca}^{2+}$ (SOC) channels (Yoshida et al. 2003) indicating a role for these channel families in differing motility phenomena.

\section{Sperm capacitation}

Mature epididymal sperm acquire competence to fertilize during the sperm transit through the female reproductive tract. This complex process, called capacitation, involves several changes in sperm. These include reorganizing the plasma membrane as a consequence of cholesterol removal, extensive protein tyrosine phosphorylation, hyperpolarization of the $\mathrm{E}_{\mathrm{m}}$ and increases in $\mathrm{pH}_{\mathrm{i}}$ and $\left[\mathrm{Ca}^{2+}\right]_{i}$ (reviewed by Visconti et al. 2002, Darszon et al. 2005). Capacitation is also associated with the appearance of hyperactivated motility, which some authors still consider as part of capacitation (Visconti et al. 2002, Suarez \& Ho 2003). All these changes prime sperm to respond to the zona pellucida (ZP), the extracellular egg coat that induces the AR. Although the molecular mechanisms and the signal transduction events are only partially defined, capacitation and tyrosine-phosphorylation have been shown to be regulated by a cAMP-dependent pathway involving PKA (Visconti et al. 2002; Fig. 3).

Recently, it was proposed that the changes in membrane fluidity and organization that occur during capacitation are in part a consequence of $\mathrm{HCO}_{3}^{-}$activation of scramblases that move phospholipids in both directions across the plasma membrane (Harrison \& Gadella 2005). These changes can alter ion transport for instance of $\mathrm{Ca}^{2+}$ and $\mathrm{HCO}_{3}^{-}$itself, thus activating $\mathrm{SAC}$. It has been proposed that SAC is mainly responsible for the CAMP changes during capacitation (Esposito et al. 2004, Hess et al. 2005), although a transmembrane AC may also contribute (Fraser et al. 2005; Fig. 3).

Numerous studies have demonstrated that capacitation is dependent on different ions present in the capacitation medium, such as $\mathrm{Ca}^{2+}, \mathrm{K}^{+}, \mathrm{HCO}_{3}^{-}$and $\mathrm{Na}^{+}$(Visconti et al. 2002, Darszon et al. 2005). In vitro capacitation requires the presence of three key components: $\mathrm{Ca}^{2+}$, $\mathrm{HCO}_{3}^{-}$and bovine serum albumin (BSA). Several types of ion channels and transporters have been reported in mammalian sperm (Darszon et al. 2005; Fig. 2), but how they participate in the regulation of $\mathrm{E}_{\mathrm{m}}, \mathrm{pH}_{\mathrm{i}}$ and $\left[\mathrm{Ca}^{2+}\right]_{i}$ during capacitation is not well established. Non-capacitated sperm maintain a relatively depolarized $\mathrm{E}_{\mathrm{m}}(\sim-35$ to $-45 \mathrm{mV})$ that hyperpolarizes $(-80 \mathrm{mV})$ during capacitation (Arnoult et al. 1999, Munoz-Garay et al. 2001). This has been proposed to remove inactivation from T-type $\mathrm{Ca}_{\mathrm{v}}$ channels and recruit them to a closed state, from which they are available for opening during the induction of the AR by ZP3 (Zona Pellucida Protein 3) (discussed further below in the mammalian acrosome reaction section; Arnoult et al. 1999). The identity of the ion transport system(s) responsible for the $\left[\mathrm{Ca}^{2+}\right]_{\mathrm{i}}$ increase observed during capacitation is not known. $\mathrm{Ca}_{v}$ channels other than T-type as well as several members of the TRP family have also been identified in sperm (Fig. 2) and their precise role during capacitation, if any, remains to be established.

Since external $\mathrm{K}^{+}$and $\mathrm{K}^{+}$-channel blockers influence the hyperpolarization that accompanies mouse sperm capacitation, it is thought that the $\mathrm{K}^{+}$permeability contributes to this process (Arnoult et al. 1999, Munoz-Garay et al. 2001, Acevedo et al. 2006). Molecular and functional evidence indicate the presence of voltage-gated $\mathrm{K}^{+}$ channels (Salvatore et al. 1999), $\mathrm{Ca}^{2+}$-activated $\mathrm{K}^{+}$channels (Chan et al. 1998) and inwardly rectifying $\mathrm{K}^{+}\left(\mathrm{K}_{\mathrm{ir}}\right)$ channels (Munoz-Garay et al. 2001, Felix et al. 2002, Acevedo et al. 2006) in spermatogenic and sperm cells. Before capacitation, sperm $\mathrm{pH}_{\mathrm{i}}$ is relatively acidic and may down-regulate sperm $\mathrm{K}_{\mathrm{ir}}$ channels, thereby maintaining $E_{m}$ depolarized and indirectly preventing unregulated 


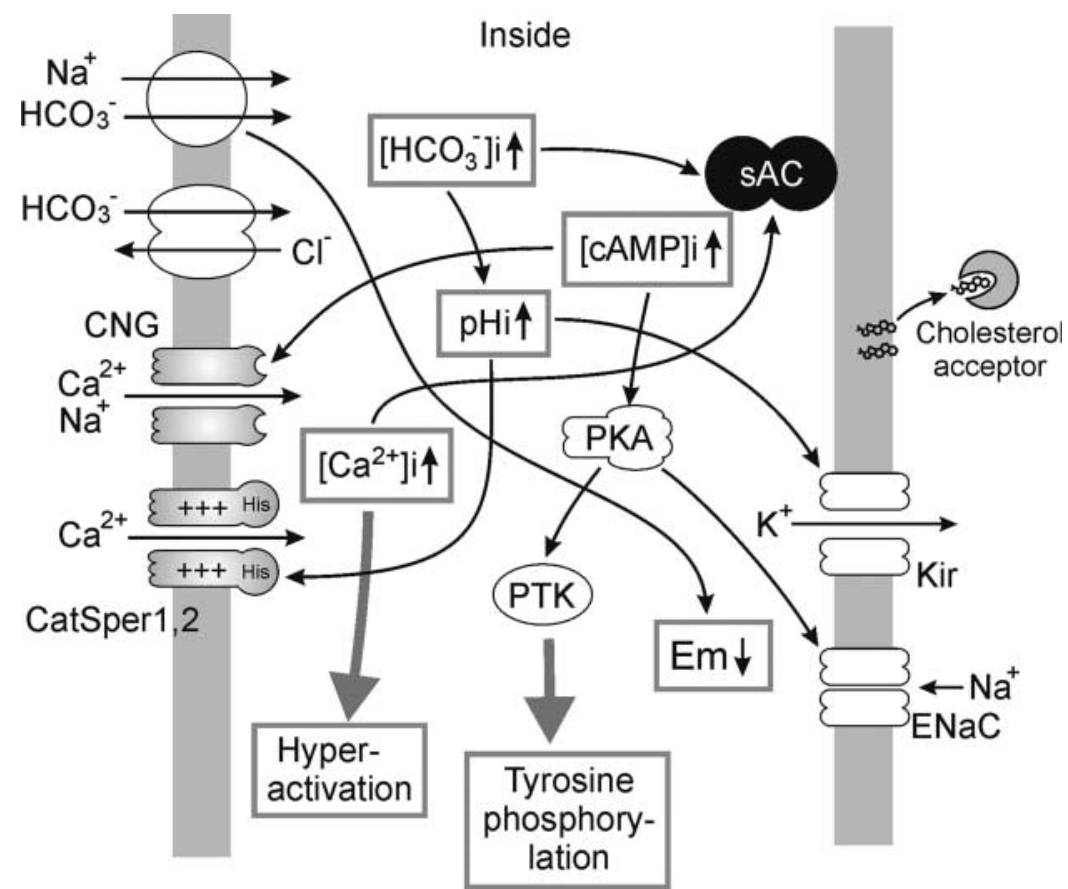

Figure 3 Diagram of ion fluxes and signaling events of mammalian sperm capacitation. Uptake of bicarbonate $\left(\mathrm{HCO}_{3}^{-}\right)$through the $\mathrm{Na}^{+}-\mathrm{HCO}_{3}^{-}$ cotransporter and other transporters stimulates SAC and CAMP elevation and lipid reorganization in the plasma membrane, respectively. Cholesterol acceptors such as albumin also promote the process of lipid reorganization. cAMP has several targets such as CNG channels, PKA and $\mathrm{ENaC}$ possibly indirectly. Also, an increase in intracellular $\mathrm{Ca}^{2+}$ may directly activate $\mathrm{SAC}$ and an increase in $\mathrm{pH}_{\mathrm{i}}$ can promote $\mathrm{Ca}^{2+}$ influx through CatSper 1 and 2 channels. Therefore, there is a cAMP, $\mathrm{Ca}^{2+}$ and $\mathrm{pH}_{\mathrm{i}}$ synergism. Furthermore, the changes in these intracellular parameters lead to tyrosine phosphorylation involving PKA activation, hyperactivation of sperm motility and the hyperpolarization by opening $\mathrm{K}^{+}$ channels $\left(\mathrm{K}_{\mathrm{ir}}\right)$ and closing ENaC. PTK; protein tyrosine kinase.

$\mathrm{Ca}^{2+}$ entry, and thus the AR (Zeng et al. 1996). The $\mathrm{pH}_{\mathrm{i}}$ increase and ATP decrease (Baker \& Aitken 2004) that accompany capacitation could activate $\mathrm{pH}$ and ATP dependent $\mathrm{K}_{\mathrm{ir}}$ channels, allowing $\mathrm{K}^{+}$efflux and the consequent hyperpolarization of sperm.

An $\mathrm{Na}^{+} / \mathrm{HCO}_{3}^{-}$cotransporter has also been shown to hyperpolarize mouse sperm $\mathrm{E}_{\mathrm{m}}$ upon the increase in external $\mathrm{HCO}_{3}^{-}$that occurs during ejaculation (Demarco et al. 2003). On the other hand, inhibition of an electrogenic $\mathrm{Na}^{+}$sperm permeability would also result in a hyperpolarization. Epithelial $\mathrm{Na}^{+}$channels (ENaCs) are amiloridesensitive channels that contribute to the resting $E_{m}$ by displacing it towards the $\mathrm{Na}^{+}$equilibrium potential (Awayda et al. 2000). Recently, the presence of ENaCs ( $\alpha$ and $\delta$ subunits) was reported in mouse sperm (Hernandez-Gonzalez et al. 2006). The activity of these channels could explain the depolarized state observed in non-capacitated sperm. Possibly, mouse sperm ENaCs are constitutively active in non-capacitated sperm and closed during capacitation, resulting in hyperpolarization of $\mathrm{E}_{\mathrm{m}}$.

In conclusion, the data indicate that the membrane hyperpolarization associated with capacitation could be regulated by at least two different channels and a cotransporter, whose activities reflect different sperm physiological states: closed $\mathrm{K}^{+}$channels and active ENaCs maintain the membrane potential in a depolarized state, while active $\mathrm{K}^{+}$ channels and closed ENaCs produce hyperpolarization.
It is important to determine the molecular mechanisms by which these channels are regulated and the consequences for capacitation. For example, the cystic fibrosis transmembrane conductance regulator (CFTR) $\mathrm{Cl}^{-}$channel is an important regulator of ENaCs, among other channels. Perhaps, a signaling pathway dependent on cAMP/PKA is involved in the regulation of ENaCs during capacitation.

\section{Acrosome reaction in marine sperm}

Sperm from marine external fertilizers undergo the AR when encountering the outer investment of the egg (egg jelly, Ej; Yanagimachi 1994). Commonly, the speciesspecific AR inducing factor, a major component of the EJ, is a sulfated polysaccharide. Small structural differences determine species specificity. In many marine organisms the AR comprises the exocytosis of the acrosomal vesicle and the $\mathrm{pH}_{\mathrm{i}}$-dependent polymerization of actin, leading to the extension of the acrosomal tubule (reviewed in Darszon et al. 2005). In sea urchin sperm, the tubule is covered with bindin, a protein which interacts with a receptor when it fuses with the homologous egg. The fucose sulfate polymer (FSP) binds to its sperm receptor (suREJ1) localized at the tip of the head over the acrosome and along the flagellum, and triggers $\mathrm{K}^{+}$-dependent changes in $\mathrm{E}_{\mathrm{m}}$ and increases in $\left[\mathrm{Ca}^{2+}\right]_{\mathrm{i}}, \mathrm{pH}_{\mathrm{i}},\left[\mathrm{Na}^{+}\right]_{\mathrm{i}}, \mathrm{cAMP}$ and $\mathrm{IP}_{3}$. In addition, FSP stimulates PKA, phospholipase D and nitric 
oxide synthase activities (Neill \& Vacquier 2004, Darszon et al. 2005).

The fusion of plasma and acrosomal membrane during the AR produces hybrid vesicles (HVs) that contain at least three types of ionic channels. A cAMP activated cationic channel sensitive to $\mathrm{Ba}^{2+}$ was most frequently encountered in black lipid membrane (BLM) recordings (Schulz et al. 2004). Ionic channels from flagellar membranes with similar characteristics have been also identified in BLMs (Labarca et al. 1996) and patch-clamp techniques in sea urchin sperm (Sanchez et al. 2001). The two other channels were also cationic and had larger conductances (Schulz et al. 2004).

Besides suREJ1, sea urchin sperm contain suREJ2 and suREJ3 that have been cloned and sequenced. The three sUREJ proteins possess a REJ module, shared by the human autosomal dominant polycystic kidney disease (ADPKD) protein, polycystin-1 (PC1), and by PCREJ, a testis-specific protein in mammals of unknown function. ADPKD is caused by mutations in the PKD1 and PKD2 genes, encoding the transmembrane proteins $\mathrm{PC} 1$ and $\mathrm{PC} 2$ respectively (Neill \& Vacquier 2004). In mammals PC1 and PC2 associate to form non-selective cation channels (Xu et al. 2003). PC2 or TRPP2, a member of the TRP superfamily of proteins, has amino acid sequence similarity to $\mathrm{Ca}_{\mathrm{v}}$ and other cation channels (Nilius \& Voets 2005). This protein itself forms $\mathrm{Ca}^{2+}$-permeable nonselective channels that may be involved in ligand binding (Ikeda \& Guggino 2002).

sUREJ3 includes a C-terminal transmembrane region that is homologous to $\mathrm{Ca}_{v}$ channels which has been implicated in associations with PC2 (Xu et al. 2003). Indeed, sea urchin sperm possess a PC2 homolog (suPC2) associated with suREJ 3 in the sperm plasma membrane in a thin band overlying the acrosomal vesicle (Mengerink et al. 2002, Neill \& Vacquier 2004). Notably, a high-conductance, $\mathrm{Ca}^{2+}$-permeable channel, whose properties resemble some of those displayed by the PC1-PC2 channels, has been recorded in BLMs containing sea urchin or mouse sperm plasma membranes (Lievano et al. 1990, Beltran et al. 1994). The sea urchin sperm channel discriminates poorly between monovalent and divalent cations ( $P C \mathrm{Ca} / P \mathrm{Na} \sim 5$; Lievano et al. 1990). This evidence suggests that REJ and PC proteins may be involved in the ion fluxes that follow binding of FSP and lead to the AR. As described later, TRP channels are present in mouse sperm where they seem to participate in the AR (Jungnickel et al. 2001, Trevino et al. 2001).

$\mathrm{Ca}^{2+}$ uptake during the sea urchin sperm AR precedes the changes in $\mathrm{pH}_{\mathrm{i}}$ and $\left[\mathrm{Na}^{+}\right]_{\mathrm{i}}$ and is mediated at least by two different $\mathrm{Ca}^{2+}$ channels (Rodriguez \& Darszon 2003). FSP triggers a fast transient increase in $\left[\mathrm{Ca}^{2+}\right]_{i}$ that is sensitive to verapamil and dihydropyridines (DHPs; $\mathrm{Ca}_{v}$ channel blockers that inhibit the AR). Five seconds later, a second $\mathrm{Ca}^{2+}$ channel insensitive to the latter blockers, permeable to $\mathrm{Mn}^{2+}$ and $\mathrm{Na}^{+}$, and $\mathrm{pH}_{\mathrm{i}}$ dependent, opens for minutes and leads to the sperm AR. Interestingly, one of the first two $\mathrm{Ca}_{v}$ channel orthologs $\left(\mathrm{Ca}_{v} 2.3\right)$ recently identified in Strongylocentrotus purpuratus sea urchin sperm is preferentially localized in the acrosome area (Granados-Gonzalez et al. 2005). On the other hand, as in the mammalian sperm AR (Santi et al. 1998, O'Toole et al. 2000, Jungnickel et al. 2001), the second channel appears to be a SOC channel (Gonzalez-Martinez et al. 2001). Indeed, $I_{3}$ receptors have been detected in sea urchin sperm, possibly in the acrosome (Zapata et al. 1997). It is known that $\mathrm{IP}_{3}$-mediated release of $\mathrm{Ca}^{2+}$ from intracellular stores activate SOCs (Nilius \& Voets 2005). Though not a physiological event, the second channel can be opened by a lower molecular weight $(\sim 60 \mathrm{kDa})$ hydrolyzed form of FSP, which can increase $\left[\mathrm{Ca}^{2+}\right]_{i}$ but does not induce AR by itself (Hirohashi \& Vacquier 2002). Namely, activation of this second channel alone causes acrosomal exocytosis but not acrosomal actin polymerization (Hirohashi \& Vacquier 2003).

Elevation of the $\left[\mathrm{K}^{+}\right]_{\mathrm{e}}$ to $30-50 \mathrm{mM}$ or addition of tetraethylammonium (TEA), a $\mathrm{K}^{+}$channel blocker, inhibits the $\mathrm{AR}$ and the increases in $\left[\mathrm{Ca}^{2+}\right]_{\mathrm{i}}$ and $\mathrm{pH}_{\mathrm{i}}$ associated to this reaction in S. purpuratus sperm (Darszon et al. 2005). These results suggest the participation of $\mathrm{K}^{+}$channels in the AR. In L. pictus sperm, binding of FSP induces a fast $\mathrm{K}^{+}$-dependent hyperpolarization (Gonzalez-Martinez \& Darszon 1987) which precedes and probably leads to the activation of a $\mathrm{Ca}^{2+}$-dependent $\mathrm{Na}^{+} / \mathrm{H}^{+}$exchange that in turn increases $\mathrm{pH}_{\mathrm{i}}$ (Gonzalez-Martinez et al. 1992). This hyperpolarization could remove inactivation from $\mathrm{Ca}_{\mathrm{v}}$ channels (Gonzalez-Martinez \& Darszon 1987, Lievano et al. 1990).

Besides $\mathrm{Ca}^{2+}$ channels, $\mathrm{TEA}^{+}$-sensitive $\mathrm{K}^{+}$(Lievano et al. 1985, Gonzalez-Martinez et al. 1992, Labarca et al. 1996) and $\mathrm{Cl}^{-}$channels have been recorded in planar bilayers with incorporated S. purpuratus sperm plasma membranes. The sea urchin AR is inhibited by $4,4^{\prime}$-diisothiocyanatostilbene-2-2'-disulfonic acid (DIDS), an anion channel and transporter blocker (Morales et al. 1993). The sensitivity of some of the ion channels recorded in planar bilayers to inhibitors of the AR is consistent with their involvement in this fundamental event (Darszon et al. 2005).

\section{Acrosome reaction in mammalian sperm}

After traveling to find the egg, sperm must recognize its extracellular coat, the zona pellucida (ZP) and bind to it. The AR allows sperm to penetrate this layer and fuse with the egg. This process is accompanied by the release of lytic enzymes and the fusion of the acrosome and plasma membranes in the sperm head. Among the components of $\mathrm{ZP}, \mathrm{ZP} 3$ is recognized as the natural AR inducer. The ZP3 receptor has not been unequivocally identified in the sperm plasma membrane though several candidates exist (Jovine et al. 2005). The signaling cascade that culminates with the AR is not fully understood but intensive research has shed light on this crucial phenomenon (Fig. 4). ZP and other agents like progesterone trigger AR by influencing 
A
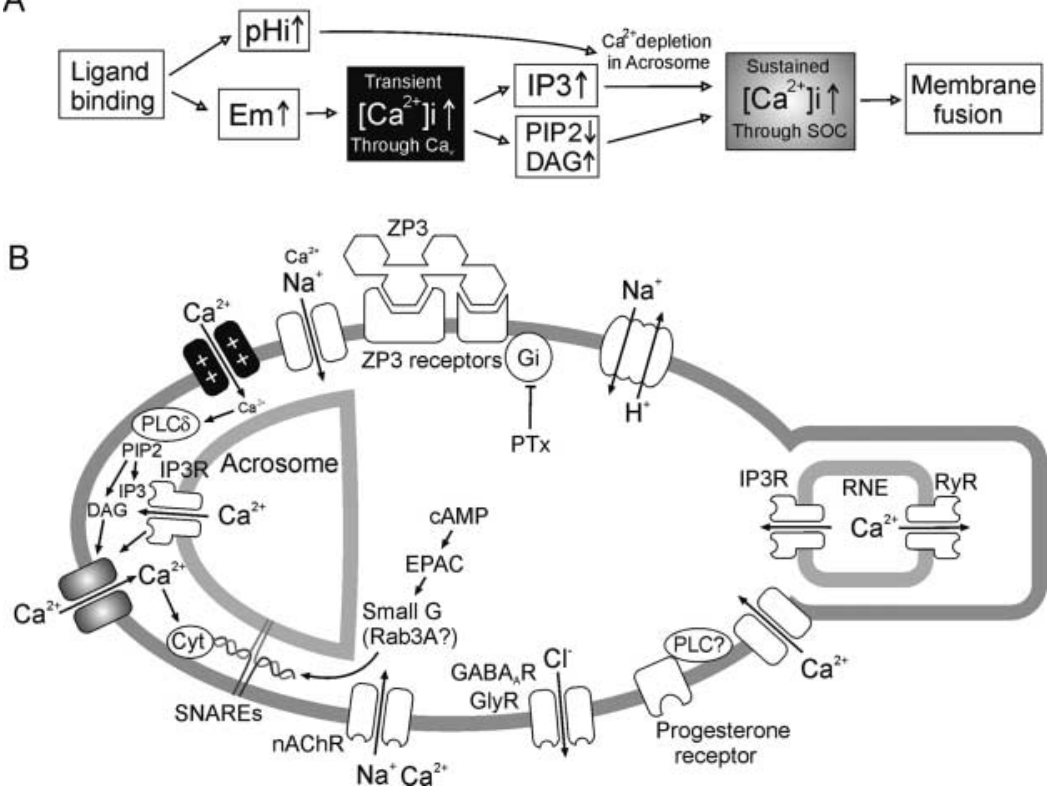

Figure 4 (A) Intracellular changes elicited upon ligand binding to sperm receptors during the acrosome reaction (AR). Initially there are increases in $\mathrm{E}_{\mathrm{m}}, \mathrm{pH}_{\mathrm{i}}$ and a $\mathrm{Ca}^{2+}$ transient. Production of $\mathrm{IP}_{3}$ causes $\mathrm{Ca}^{2+}$ store depletion that results in SOC channel opening responsible for the sustained $\mathrm{Ca}^{2+}$ increase that precedes the AR. (B) Channels and molecules involved in the changes that lead to the mammalian sperm AR. ZP3 binding to its receptor: activates a $\mathrm{G}_{\mathrm{i}}$ protein involved in the $\mathrm{pH}_{\mathrm{i}}$ change possibly mediated by $\mathrm{Na}^{+} / \mathrm{H}^{+}$transporters; causes membrane depolarization (possibly by GABA, ACh and Gly receptors or an unidentified cation channel) that opens $\mathrm{Ca}_{v}$ channels which cause the initial $\mathrm{Ca}^{2+}$ transient influx; $\mathrm{Ca}^{2+}$ activation of PLC $\delta$ generates diacylglycerol (DAG) and $\mathrm{IP}_{3}$ consuming its substrate, $\mathrm{PIP}_{2} . \mathrm{IP}_{3}$ thereafter binds to its receptor and causes $\mathrm{Ca}^{2+}$-store depletion which in turn (possibly in conjunction with DAG) activates SOC channels at the plasma membrane. Ca ${ }^{2+}$, CAMP and small G proteins act together to activate the SNARE machinery required for membrane fusion. SNAREs, soluble N-ethylmaleimide-sensitive factor attachment protein receptors; PTx, pertussis toxin; EPAC, exchange protein directly activated by; Cyt, Synaptotagmin.

ion fluxes, phospholipid metabolism, cAMP levels, and protein phosphorylation. During the AR there are increases in $\left[\mathrm{Ca}^{2+}\right]_{i}$ and $\mathrm{pH}_{\mathrm{i}}$, the latter being sensitive to pertussis toxin (PTx) that inactivates $G_{i}$ proteins. The current model proposes that ZP3 binding generates a biphasic $\mathrm{Ca}^{2+}$ response involving at least three separate yet sequentially-linked $\mathrm{Ca}^{2+}$ channels. In mouse sperm, initially $\left[\mathrm{Ca}^{2+}\right]_{i}$ elevates to micromolar levels within $50 \mathrm{~ms}$ and relaxes back to resting values within $200 \mathrm{~ms}$. The pharmacology and kinetics of this excursion are consistent with opening of T-type $\mathrm{Ca}_{v}$ channels $\left(\mathrm{Ca}_{v} 3\right.$; Arnoult et al. 1999). Furthermore, the AR can be inhibited by several $\mathrm{Ca}_{\mathrm{v}} 3$ channel antagonists such as DHPs, pimozide and $\mathrm{Ni}^{2+}$. Molecules such as urocortin, fenvalerate and gossypol have been shown to inhibit T-type currents in spermatogenic cells and may have contraceptive applications (Bai \& Shi 2002, Tao et al. 2005, Xiao et al. 2006). This family of $\mathrm{Ca}_{v}$ s has three members, all of them have been immunolocalized in mammalian sperm. $\mathrm{Ca}_{v} 3.1$ and $\mathrm{Ca}_{v} 3.2$ localize to the acrosomal region, however, knockout mice for these two $\mathrm{Ca}_{\mathrm{v}}$ isoforms are fertile (Chen et al. 2003, Stamboulian et al. 2004), and it could be that double $\mathrm{Ca}_{v}$ channel knockouts would help clarify the role of these channels. The participation of $\mathrm{Ca}_{\mathrm{v}} 3$ in the human sperm AR is much less clear. Additionally, other members of the $\mathrm{Ca}_{v}$ superfamily and CatSpers (Lobley et al. 2003) have been identified in mammalian sperm (Fig. 2) but their function remains unknown (Guzman-Grenfell \& Gonzalez-Martinez 2004).

The second $\left[\mathrm{Ca}^{2+}\right]_{i}$ rise is slower and sustained, lasting several minutes and is necessary for AR completion. ZP3 binding causes an $\mathrm{IP}_{3}$ increase which in turn releases $\mathrm{Ca}^{2+}$ from the acrosome - the sperm $\mathrm{Ca}^{2+}$ store (Walensky \& Snyder 1995, De Blas et al. 2002). The evidence supporting this model includes the identification of the $\mathrm{Ca}^{2+}$-sensitive PLC84 in sperm, with the PLC $\delta 4$ null mouse being infertile. Furthermore, $\mathrm{IP}_{3}$ receptors have been immunolocalized to the acrosome and also to the RNE. This generation of $\mathrm{IP}_{3}$ and emptying of intracellular $\mathrm{Ca}^{2+}$ stores, as in somatic cells, leads to a further $\left[\mathrm{Ca}^{2+}\right]_{i}$ increase due to opening of SOCs at the plasma membrane. It is likely that the SOC is a member of the TRP family. TRPC2 has been implicated in the ZP3-induced mouse AR (Jungnickel et al. 2001) and the acrosome region of these sperm contains at least TRPC1, 2 and 5 (Fig. 2). Maitotoxin, which induces $\mathrm{Ca}^{2+}$ uptake through its action on TRPs, is the most potent AR inducer aside from ZP (Trevino et al. 2006). The possible participation of more than one TRP cannot be discarded due to the fact that TRPC2 null mice are fertile (Stowers et al. 2002) and that TRPC channels can form heteromultimers (Nilius \& Voets 2005).

An unresolved question is how the TRP channels involved in the AR are activated? There are several hypotheses and the diversity of this family means it is unlikely that 
a single mechanism exists. Recently several TRP regulating molecules have been identified and it is worthwhile exploring their participation in the AR signaling cascade. STIM (Stromal Interaction Molecule) is a TRP-interacting protein that translocates from the ER to the plasma membrane to function either as the communication factor between the $\mathrm{Ca}^{2+}$-store and the plasma membrane or forming part of the channel itself (Zhang et al. 2005). TRP channels can also be regulated by phosphatidylinositol biphosphate $\left(\mathrm{PIP}_{2}\right.$; Suh \& Hille 2005) and by newly discovered regulatory proteins such as junctate (Stamboulian et al. 2005) and enkurin (Sutton et al. 2004) that bind specifically to certain TRP isoforms modulating their activity.

There are other agonists such as progesterone, gammaaminobutyric acid (GABA), acetylcholine (ACh) and glycine that can induce the AR but their physiological significance remains to be established. The presence of ionotropic receptors for GABA $\left(\mathrm{GABA}_{\mathrm{A}} \mathrm{R}\right)($ Wistrom \& Meizel 1993) ACh (Kumar \& Meizel 2005) and glycine (GlyR) (Sato et al. 2000) in sperm has been documented and mutant mice for nAChR (null) and GlyR (point mutation) showed reduced ZP-induced AR and in vitro fertility (Meizel \& Son 2005). Considering that intracellular $\mathrm{Cl}^{-}$was estimated to be $40 \mathrm{mM}$ in capacitated human sperm, opening of $\mathrm{Cl}^{-}$channels, such as the GABAAR receptor or the GlyR, should result in $\mathrm{Cl}^{-}$efflux, leading to depolarization of the $E_{m}$ (Garcia \& Meizel 1999). The proposal is that these neurotransmitter receptors are responsible for the initial depolarization required to activate the $\mathrm{Ca}_{\mathrm{v}}$ channels involved in the initial $\mathrm{Ca}^{2+}$ rise.

In human sperm, progesterone also induces a biphasic $\mathrm{Ca}^{2+}$ response similar to that of ZP3. However, when applied as a gradient (simulating the physiological conditions), the initial $\mathrm{Ca}^{2+}$ rise is replaced by oscillations proposed to be mediated by RyR-like receptors (Harper et al. 2004). These results suggest progesterone may help sperm to penetrate through the egg coat by inducing hyperactivation-like flagellar movement as well as the AR.

\section{Concluding remarks}

Recent developments in the tools available to study ion channels are improving our understanding of how these integral membrane proteins operate and are regulated in the sperm. Voltage and ion-sensitive fluorescent dye imaging, novel patch-clamp approaches, bilayer reconstitution, molecular biology and the growing number of available genomes are unveiling the fascinating and often unique properties of sperm ion channels. Correlating ion channel location and function will enable us to understand how these proteins participate in the finely orchestrated sperm functions involved in generating a new individual.

\section{Acknowledgements}

This work was supported by: DGAPA (IN225406-3 to A Darszon, IN225806-3 to C Beltrán and IN227806-3 to C
Treviño), CONACyT (39908-Q to A Darszon and 39939-Q to C Beltrán) and by the Wellcome Trust and FIRCA RO3 TW 006121 to A Darszon. The authors declare that there is no conflict of interest that would prejudice the impartiality of this scientific work.

\section{References}

Acevedo JJ, Mendoza-Lujambio I, de la Vega-Beltran JL, Trevino CL, Felix R \& Darszon A 2006 K(ATP) channels in mouse spermatogenic cells and sperm, and their role in capacitation. Developmental Biology 289 395-405.

Arnoult C, Cardullo RA, Lemos JR \& Florman HM 1996 Activation of mouse sperm T-type Ca2 + channels by adhesion to the egg zona pellucida. PNAS 93 13004-13009.

Arnoult C, Kazam IG, Visconti PE, Kopf GS, Villaz M \& Florman HM 1999 Control of the low voltage-activated calcium channel of mouse sperm by egg ZP3 and by membrane hyperpolarization during capacitation. PNAS 96 6757-6762.

Awayda MS, Boudreaux MJ, Reger RL \& Hamm LL 2000 Regulation of the epithelial $\mathrm{Na}(+)$ channel by extracellular acidification. American Journal of Physiology, Cell Physiology 279 C1896-C1905.

Bai J \& Shi Y 2002 Inhibition of T-type $\mathrm{Ca}(2+)$ currents in mouse spermatogenic cells by gossypol, an antifertility compound. European Journal of Pharmacology $4401-6$.

Baker MA \& Aitken RJ 2004 The importance of redox regulated pathways in sperm cell biology. Molecular and Cellular Endocrinology $21647-54$

Baldi E, Luconi M, Bonaccorsi L \& Forti G 2002 Signal transduction pathways in human spermatozoa. Journal of Reproductive Immunology 53 121-131.

Beltran C, Darszon A, Labarca P \& Lievano A 1994 A high-conductance voltage-dependent multistate $\mathrm{Ca} 2+$ channel found in sea urchin and mouse spermatozoa. FEBS Letters 338 23-26.

Bohmer M, Van Q, Weyand I, Hagen V, Beyermann M, Matsumoto M, Hoshi M, Hildebrand E \& Kaupp UB 2005 Ca2 + spikes in the flagellum control chemotactic behavior of sperm. EMBO Journal $242741-2752$.

Brokaw CJ 1979 Calcium-induced asymmetrical beating of tritondemembranated sea urchin sperm flagella. Journal of Cell Biology $82401-411$.

Carlson AE, Quill TA, Westenbroek RE, Schuh SM, Hille B \& Babcock DF 2005 Identical phenotypes of CatSper1 and CatSper2 null sperm. Journal of Biological Chemistry 280 32238-32244.

Carlson AE, Westenbroek RE, Quill T, Ren D, Clapham DE, Hille B, Garbers DL \& Babcock DF 2003 CatSper1 required for evoked $\mathrm{Ca}^{2+}$ entry and control of flagellar function in sperm. PNAS $\mathbf{1 0 0}$ 14864-14868.

Castellano LE, Trevino CL, Rodriguez D, Serrano CJ, Pacheco J, Tsutsumi V, Felix R \& Darszon A 2003 Transient receptor potential (TRPC) channels in human sperm: expression, cellular localization and involvement in the regulation of flagellar motility. FEBS Letters $54169-74$.

Chan HC, Wu WL, Sun YP, Leung PS, Wong TP, Chung YW, So SC, Zhou TS \& Yan YC 1998 Expression of sperm Ca2 + -activated $\mathrm{K}+$ channels in Xenopus oocytes and their modulation by extracellular ATP. FEBS Letters 438 177-182.

Chen CC, Lamping KG, Nuno DW, Barresi R, Prouty SJ, Lavoie JL, Cribbs LL, England SK, Sigmund CD, Weiss RM, Williamson RA, Hill JA \& Campbell KP 2003 Abnormal coronary function in mice deficient in alpha1H T-type Ca2 + channels. Science 302 1416-1418.

Darszon A, Nishigaki T, Wood C, Trevino CL, Felix R \& Beltran C 2005 Calcium channels and Ca2 + fluctuations in sperm physiology. International Review of Cytology 243 79-172.

De Blas G, Michaut M, Trevino CL, Tomes CN, Yunes R, Darszon A \& Mayorga LS 2002 The intraacrosomal calcium pool plays a direct role in acrosomal exocytosis. Journal of Biological Chemistry 277 49326-49331. 
Demarco IA, Espinosa F, Edwards J, Sosnik J, De La Vega-Beltran JL, Hockensmith JW, Kopf GS, Darszon A \& Visconti PE 2003 Involvement of a $\mathrm{Na}+/ \mathrm{HCO}-3$ cotransporter in mouse sperm capacitation. Journal of Biological Chemistry 278 7001-7009.

Eisenbach M 1999 Sperm chemotaxis. Reviews of Reproduction 4 $56-66$.

Espinosa F \& Darszon A 1995 Mouse sperm membrane potential: changes induced by Ca2 +. FEBS Letters 372 119-125.

Esposito G, Jaiswal BS, Xie F, Krajnc-Franken MA, Robben TJ, Strik AM, Kuil C, Philipsen RL, van Duin M, Conti M \& Gossen JA 2004 Mice deficient for soluble adenylyl cyclase are infertile because of a severe sperm-motility defect. PNAS 101 2993-2998.

Felix R, Serrano CJ, Trevino CL, Munoz-Garay C, Bravo A, Navarro A, Pacheco J, Tsutsumi V \& Darszon A 2002 Identification of distinct $\mathrm{K}+$ channels in mouse spermatogenic cells and sperm. Zygote $10183-188$.

Fraire-Zamora JJ \& Gonzalez-Martinez MT 2004 Effect of intracellular $\mathrm{pH}$ on depolarization-evoked calcium influx in human sperm. American Journal of Physiology, Cell Physiology 287 C1688-C1696.

Fraser LR, Adeoya-Osiguwa S, Baxendale RW, Mededovic S \& Osiguwa OO 2005 First messenger regulation of mammalian sperm function via adenylyl cyclase/cAMP. Journal of Reproduction and Development 51 37-46.

Galindo BE, Neill AT \& Vacquier VD 2005 A new hyperpolarizationactivated, cyclic nucleotide-gated channel from sea urchin sperm flagella. Biochemical and Biophysical Research Communications 334 96-101.

Garcia MA \& Meizel S 1999 Determination of the steady-state intracellular chloride concentration incapacitated human spermatozoa. Journal of Andrology 20 88-93.

Gauss R, Seifert R \& Kaupp UB 1998 Molecular identification of a hyperpolarization-activated channel in sea urchin sperm. Nature $393583-587$.

Gonzalez-Martinez M \& Darszon A 1987 A fast transient hyperpolarization occurs during the sea urchin sperm acrosome reaction induced by egg jelly. FEBS Letters 218 247-250.

Gonzalez-Martinez MT 2003 Induction of a sodium-dependent depolarization by external calcium removal in human sperm. Journal of Biological Chemistry 278 36304-36310.

Gonzalez-Martinez MT, Galindo BE, de De La Torre L, Zapata O, Rodriguez E, Florman HM \& Darszon A 2001 A sustained increase in intracellular $\mathrm{Ca}(2+)$ is required for the acrosome reaction in sea urchinsperm. Developmental Biology 236 220-229.

Gonzalez-Martinez MT, Guerrero A, Morales E, de De La Torre L \& Darszon A 1992 A depolarization can trigger Ca2 + uptake and the acrosome reaction when preceded by a hyperpolarization in $\mathrm{L}$. pictus sea urchin sperm. Developmental Biology 150 193-202.

Granados-Gonzalez G, Mendoza-Lujambio I, Rodriguez E, Galindo BE, Beltran C \& Darszon A 2005 Identification of voltage-dependent $\mathrm{Ca} 2+$ channels in sea urchin sperm. FEBS Letters $\mathbf{5 7 9}$ 6667-6672.

Guzman-Grenfell AM \& Gonzalez-Martinez MT 2004 Lack of voltage-dependent calcium channel opening during the calcium influx induced by progesterone in human sperm. Effect of calcium channel deactivation and inactivation. Journal of Andrology 25 117-122.

Harper CV, Barratt CL \& Publicover SJ 2004 Stimulation of human spermatozoa with progesterone gradients to simulate approach to the oocyte. Induction of $[\mathrm{Ca}(2+)](\mathrm{i})$ oscillations and cyclical transitions in flagellar beating. Journal of Biological Chemistry 279 46315-46325.

Harrison RA \& Gadella BM 2005 Bicarbonate-induced membrane processing in sperm capacitation. Theriogenology 63 342-351.

Hernandez-Gonzalez EO, Sosnik J, Edwards J, Acevedo JJ, MendozaLujambio I, Lopez-Gonzalez I, Demarco I, Wertheimer E, Darszon A \& Visconti PE 2006 Sodium and epithelial sodium channels participate in the regulation of the capacitation-associated hyperpolarization in mouse sperm. Journal of Biological Chemistry $2815623-5633$.
Hess KC, Jones BH, Marquez B, Chen Y, Ord TS, Kamenetsky M, Miyamoto C, Zippin JH, Kopf GS, Suarez SS, Levin LR, Williams CJ, Buck J \& Moss SB 2005 The 'soluble' adenylyl cyclase in sperm mediates multiple signaling events required for fertilization. Developmental Cell 9 249-259.

Hildebrand E \& Kaupp UB 2005 Sperm chemotaxis: a primer. Annals of the New York Academies of Science 1061 221-225.

Hirohashi N \& Vacquier VD 2002 Egg sialoglycans increase intracellular $\mathrm{pH}$ and potentiate the acrosome reaction of sea urchin sperm. Journal of Biological Chemistry 277 8041-8047.

Hirohashi N \& Vacquier VD 2003 Store-operated calcium channels trigger exocytosis of the sea urchin sperm acrosomal vesicle. Biochemical and Biophysical Research Communications 304 285-292.

Ho HC \& Suarez SS 2003 Characterization of the intracellular calcium store at the base of the sperm flagellum that regulates hyperactivated motility. Biology of Reproduction 68 1590-1596.

Ikeda M \& Guggino WB 2002 Do polycystins function as cation channels? Current Opinion in Nephrology and Hypertension 11 $539-545$.

Jimenez-Gonzalez C, Michelangeli F, Harper CV, Barratt CL \& Publicover SJ 2006 Calcium signalling in human spermatozoa: a specialized 'toolkit' of channels, transporters and stores. Human Reproduction Update 12 253-267.

Jin JL, O'Doherty AM, Wang S, Zheng H, Sanders KM \& Yan W 2005 Catsper3 and catsper4 encode two cation channel-like proteins exclusively expressed in the testis. Biology of Reproduction 73 1235-1242.

Jovine L, Darie CC, Litscher ES \& Wassarman PM 2005 Zona pellucida domain proteins. Annual Reviews of Biochemistry $\mathbf{7 4}$ 83-114.

Jungnickel MK, Sutton KA \& Florman HM 2003 In the beginning: lessons from fertilization in mice and worms. Cell 114 401-404.

Jungnickel MK, Marrero H, Birnbaumer L, Lemos JR \& Florman HM 2001 Trp2 regulates entry of $\mathrm{Ca} 2+$ into mouse sperm triggered by egg ZP3. Nature Cell Biology 3 499-502.

Kirichok Y, Navarro B \& Clapham DE 2006 Whole-cell patch-clamp measurements of spermatozoa reveal an alkaline-activated Ca2 + channel. Nature 439 737-740.

Kumar P \& Meizel S 2005 Nicotinic acetylcholine receptor subunits and associated proteins in human sperm. Journal of Biological Chemistry $28025928-25935$.

Labarca P, Santi C, Zapata O, Morales E, Beltr'an C, Li'evano A \& Darszon A 1996 A cAMP regulated K + -selective channel from the sea urchin sperm plasma membrane. Developmental Biology $174271-280$.

Lievano A, Sanchez JA \& Darszon A 1985 Single-channel activity of bilayers derived from sea urchin sperm plasma membranes at the tip of a patch-clamp electrode. Developmental Biology 112 $253-257$

Lievano A, Vega-SaenzdeMiera EC \& Darszon A 1990 Ca2 + channels from the sea urchin sperm plasma membrane. Journal of General Physiology 95 273-296.

Litvin TN, Kamenetsky M, Zarifyan A, Buck J \& Levin LR 2003 Kinetic properties of 'soluble' adenylyl cyclase. Synergism between calcium and bicarbonate. Journal of Biological Chemistry 278 $15922-15926$.

Lobley A, Pierron V, Reynolds L, Allen L \& Michalovich D 2003 Identification of human and mouse CatSper 3 and CatSper 4 genes: Characterisation of a common interaction domain and evidence for expression in testis. Reproductive Biology and Endocrinology 1 $53-67$.

Meizel S \& Son JH 2005 Studies of sperm from mutant mice suggesting that two neurotransmitter receptors are important to the zona pellucida-initiated acrosome reaction. Molecular Reproduction and Development 72 250-258.

Mengerink KJ, Moy GW \& Vacquier VD 2002 suREJ3, a polycystin-1 protein, is cleaved at the GPS domain and localizes to the acroso- 
mal region of sea urchin sperm. Journal of Biological Chemistry 277 943-948.

Morales E, de la Torre L, Moy GW, Vacquier VD \& Darszon A 1993 Anion channels in the sea urchin sperm plasma membrane. Molecular Reproduction and Development 36 174-182.

Morisawa M 1994 Cell signaling mechanisms for sperm motility. Zoological Science 11 647-662.

Munoz-Garay C, De la Vega-Beltran JL, Delgado R, Labarca P, Felix R \& Darszon A 2001 Inwardly rectifying $\mathrm{K}(+)$ channels in spermatogenic cells: functional expression and implication in sperm capacitation. Developmental Biology 234 261-274.

Neill AT \& Vacquier VD 2004 Ligands and receptors mediating signal transduction in sea urchin spermatozoa. Reproduction 127 $141-149$.

Nilius B \& Voets T 2005 TRP channels: a TR(I)P through a world of multifunctional cation channels. Pflugers Archiv 451 1-10.

Nishigaki T, Wood CD, Tatsu Y, Yumoto N, Furuta T, Elias D, Shiba K, Baba SA \& Darszon A 2004 A sea urchin egg jelly peptide induces a cGMP-mediated decrease in sperm intracellular $\mathrm{Ca}(2+)$ before its increase. Developmental Biology 272 376-388.

O'Toole CM, Arnoult C, Darszon A, Steinhardt RA \& Florman HM $2000 \mathrm{Ca}(2+)$ entry through store-operated channels in mouse sperm is initiated by egg ZP3 and drives the acrosome reaction. Molecular Biology of the Cell 11 1571-1584.

Quill TA, Ren D, Clapham DE \& Garbers DL 2001 A voltage-gated ion channel expressed specifically in spermatozoa. PNAS $\mathbf{9 8}$ 12527-12531.

Quill TA, Sugden SA, Rossi KL, Doolittle LK, Hammer RE \& Garbers DL 2003 Hyperactivated sperm motility driven by CatSper2 is required for fertilization. PNAS 100 14869-14874.

Quill TA, Wang D \& Garbers DL 2006 Insights into sperm cell motility signaling through sNHE and the CatSpers. Molecular and Cellular Endocrinology [in press].

Ren D, Navarro B, Perez G, Jackson AC, Hsu S, Shi Q, Tilly JL \& Clapham DE 2001 A sperm ion channel required for sperm motility and male fertility. Nature 413 603-609.

Rodriguez E \& Darszon A 2003 Intracellular sodium changes during the speract response and the acrosome reaction in sea urchin sperm. Journal of Physiology 546 89-100.

Sakata Y, Saegusa H, Zong S, Osanai M, Murakoshi T, Shimizu Y, Noda T, Aso T \& Tanabe T $2002 \mathrm{Ca}(\mathrm{v}) 2.3$ (alpha1E) Ca2 + channel participates in the control of sperm function. FEBS Letters 516 229-233.

Salvatore L, D'Adamo MC, Polishchuk R, Salmona M \& Pessia M 1999 Localization and age-dependent expression of the inward rectifier $\mathrm{K}+$ channel subunit Kir 5.1 in a mammalian reproductive system. FEBS Letters 449 146-152.

Sanchez D, Labarca P \& Darszon A 2001 Sea urchin sperm cationselective channels directly modulated by cAMP. FEBS Letters $\mathbf{5 0 3}$ $111-115$.

Santi CM, Santos T, Hernandez-Cruz A \& Darszon A 1998 Properties of a novel $\mathrm{pH}$-dependent $\mathrm{Ca} 2+$ permeation pathway present in male germ cells with possible roles in spermatogenesis and mature sperm function. Journal of General Physiology 112 33-53.

Sato Y, Son JH \& Meizel S 2000 The mouse sperm glycine receptor/chloride channel: cellular localization and involvement in the acrosome reaction initiated by glycine. Journal of Andrology $\mathbf{2 1}$ 99-106.

Schulz JR, De la Vega-Beltran JL, Beltran C, Vacquier VD \& Darszon A 2004 lon channel activity of membrane vesicles released from sea urchin sperm during the acrosome reaction. Biochemical and Biophysical Research Communications 321 88-93.

Serrano CJ, Trevino CL, Felix R \& Darszon A 1999 Voltage-dependent $\mathrm{Ca}(2+)$ channel subunit expression and immunolocalization in mouse spermatogenic cells and sperm. FEBS Letters 462 171-176.

Stamboulian S, Kim D, Shin HS, Ronjat M, De Waard M \& Arnoult C 2004 Biophysical and pharmacological characterization of spermatogenic T-type calcium current in mice lacking the CaV3.1 (alpha1G) calcium channel: CaV3.2 (alpha1H) is the main func- tional calcium channel in wild-type spermatogenic cells. Journal of Cell Physiology 200 116-124.

Stamboulian S, Moutin MJ, Treves S, Pochon N, Grunwald D, Zorzato F, De Waard M, Ronjat M \& Arnoult C 2005 Junctate, an inositol 1,4,5-triphosphate receptor associated protein, is present in rodent sperm and binds TRPC2 and TRPC5 but not TRPC1 channels. Developmental Biology 286 326-337.

Stowers L, Holy TE, Meister M, Dulac C \& Koentges G 2002 Loss of sex discrimination and male-male aggression in mice deficient for TRP2. Science 295 1493-1500.

Suarez SS \& Ho HC 2003 Hyperactivation of mammalian sperm. Cellular and Molecular Biology 49 351-356.

Suarez SS, Varosi SM \& Dai X 1993 Intracellular calcium increases with hyperactivation in intact, moving hamster sperm and oscillates with the flagellar beat cycle. PNAS 90 4660-4664.

Suh BC \& Hille B 2005 Regulation of ion channels by phosphatidylinositol 4,5-bisphosphate. Current Opinion in Neurobiology 15 $370-378$.

Sutton KA, Jungnickel MK, Wang Y, Cullen K, Lambert S \& Florman HM 2004 Enkurin is a novel calmodulin and TRPC channel binding protein in sperm. Developmental Biology 274 426-435.

Tao J, Wu Y, Chen J, Zhu H \& Li S 2005 Effects of urocortin on T-type calcium currents in mouse spermatogenic cells. Biochemical and Biophysical Research Communications 329 743-748.

Tash JS \& Means AR 1982 Regulation of protein phosphorylation and motility of sperm by cyclic adenosine monophosphate and calcium. Biology of Reproduction 26 745-763.

Trevino CL, De la Vega-Beltran JL, Nishigaki T, Felix R \& Darszon A 2006 Maitotoxin potently promotes $\mathrm{Ca}(2+)$ influx in mouse spermatogenic cells and sperm, and induces the acrosome reaction. Journal of Cell Physiology 206 449-456.

Trevino CL, Felix R, Castellano LE, Gutierrez C, Rodriguez D, Pacheco J, Lopez-Gonzalez I, Gomora JC, Tsutsumi V, Hernandez-Cruz A, Fiordelisio T, Scaling AL \& Darszon A 2004 Expression and differential cell distribution of low-threshold $\mathrm{Ca}(2+)$ channels in mammalian male germ cells and sperm. FEBS Letters 563 87-92.

Trevino CL, Serrano CJ, Beltran C, Felix R \& Darszon A 2001 Identification of mouse trp homologs and lipid rafts from spermatogenic cells and sperm. FEBS Letters 509 119-125.

Turner RM 2006 Moving to the beat: a review of mammalian sperm motility regulation. Reproduction, Fertility and Development $\mathbf{1 8}$ $25-38$.

Visconti PE, Westbrook VA, Chertihin O, Demarco I, Sleight S \& Diekman AB 2002 Novel signaling pathways involved in sperm acquisition of fertilizing capacity. Journal of Reproductive Immunology 53 133-150.

Walensky LD \& Snyder SH 1995 Inositol 1,4,5-trisphosphate receptors selectively localized to the acrosomes of mammalian sperm. Journal of Cell Biology 130 857-869.

Wennemuth G, Westenbroek RE, Xu T, Hille B \& Babcock DF 2000 CaV2.2 and CaV2.3 ( $\mathrm{N}$ - and R-type) Ca2 + channels in depolarization-evoked entry of $\mathrm{Ca} 2+$ into mouse sperm. Journal of Biological Chemistry 275 21210-21217.

Westenbroek RE \& Babcock DF 1999 Discrete regional distributions suggest diverse functional roles of calcium channel alpha1 subunits in sperm. Developmental Biology 207 457-469.

Weyand I, Godde M, Frings S, Weiner J, Muller F, Altenhofen W, Hatt H \& Kaupp UB 1994 Cloning and functional expression of a cyclic-nucleotide-gated channel from mammalian sperm. Nature 368 859-863.

Wiesner B, Weiner J, Middendorff R, Hagen V, Kaupp UB \& Weyand I 1998 Cyclic nucleotide-gated channels on the flagellum control Ca2 + entry into sperm. Journal of Cell Biology 142 473-484.

Wistrom CA \& Meizel S 1993 Evidence suggesting involvement of a unique human sperm steroid receptor/Cl- channel complex in the progesterone-initiated acrosome reaction. Developmental Biology $159679-690$.

Wood CD, Nishigaki T, Furuta T, Baba SA \& Darszon A 2005 Realtime analysis of the role of $\mathrm{Ca}(2+)$ in flagellar movement and 
motility in single sea urchin sperm. Journal of Cell Biology $\mathbf{1 6 9}$ $725-731$.

Xiao H, Zhang XC, Zhang L, Dai XQ, Gong W, Cheng J, Gao R \& Wang X 2006 Fenvalerate modifies T-type $\mathrm{Ca} 2+$ channels in mouse spermatogenic cells. Reproductive Toxicology 21 48-53.

Xu GM, Gonzalez-Perrett S, Essafi M, Timpanaro GA, Montalbetti N, Arnaout MA \& Cantiello HF 2003 Polycystin-1 activates and stabilizes the polycystin-2 channel. Journal of Biological Chemistry 278 1457-1462.

Yanagimachi R 1994 Mammalian Fertilization. In The Physiology of Reproduction, vol 1, pp 189-317. Eds E Knobile \& JD Neill. New York: Raven Press.

Yeung CH, Barfield JP \& Cooper TG 2006 Physiological volume regulation by spermatozoa. Molecular and Cellular Endocrinology [in press].

Yoshida M, Ishikawa M, Izumi H, De Santis R \& Morisawa M 2003 Store-operated calcium channel regulates the chemotactic behavior of ascidian sperm. PNAS $\mathbf{1 0 0}$ 149-154.

Zapata O, Ralston J, Beltran C, Parys JB, Chen JL, Longo FJ \& Darszon A 1997 Inositol triphosphate receptors in sea urchin sperm. Zygote 5 355-364.
Zeng Y, Oberdorf JA \& Florman HM $1996 \mathrm{pH}$ regulation in mouse sperm: identification of $\mathrm{Na}(+)-, \mathrm{Cl}(-)-$, and $\mathrm{HCO}_{3}^{-}(-)$-dependent and arylaminobenzoate-dependent regulatory mechanisms and characterization of their roles in sperm capacitation. Developmental Biology 173 510-520.

Zhang D \& Gopalakrishnan M 2005 Sperm ion channels: molecular targets for the next generation of contraceptive medicines? Journal of Andrology 26 643-653.

Zhang SL, Yu Y, Roos J, Kozak JA, Deerinck TJ, Ellisman MH, Stauderman KA \& Cahalan MD 2005 STIM1 is a Ca2 + sensor that activates CRAC channels and migrates from the Ca2 + store to the plasma membrane. Nature 437 902-905.

Received 1 March 2006

First decision 28 March 2006

Revised manuscript received 31 March 2006

Accepted 18 March 2006 